\title{
DIO CASSIUS AND JOHN MALALAS: TWO ANCIENT READINGS OF VIRGIL
}

The first half of this paper analyses the Greek version of Aeneid XI 371-3 found in Dio Cassius LXXV 10,2, and shows that it is more linguistically skillful than has been supposed. The second half examines the treatment of Aeneid IV 302-3 by the Byzantine chronicler John Malalas, disclosing on his part a surprising knowledge of Latin and unexpected dexterity in recreating in Greek sound effects analogous to those of the original Latin.

1. At LXXV 10, 2, Dio Cassius recount the execution of a distinguished man, the praetorian tribune Julius Crispus, by Septimius Severus ${ }^{1}$. His offence had been to quote Virgil, Aen. XI 371-3, as a bitter comment on the havoc of war: scilicet ut Turno contingat regia coniunx / nos animae uiles, inhumata infletaque turba / sternamur campis. Dio supplies this

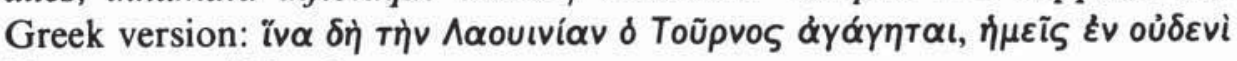
$\lambda \delta \gamma \varphi \pi \alpha \rho \alpha \pi \circ \lambda \lambda u ́ \mu \varepsilon \theta \alpha$.

Apart from damaging Gibbon's sweeping contention that the whole of Greek literature from Dionysius of Halicarnassus to Libanius contained not a single allusion to Virgil or Horace ${ }^{2}$, it is interesting for Virgilians to see that their poet is the only Latin one formally alluded to by Dio, also that a praetorian officer knew him well enough to let drop ${ }^{3}$ these lines to such grim effect. True, the anecdote is reminiscent in theme and language of part of the outburst of Thersites against Agamemnon in Iliad II 229-234, but that need not disqualify it ${ }^{4}$.

\footnotetext{
1 On this event and its background, see A. R. Birley, Septimius Severus, London 1971, pp. 203-4.

2 See further B. Baldwin, "Vergilius Graecus», AJP 97, 1976, pp. 361-8.

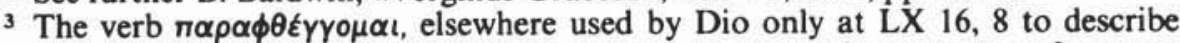
Greek words let slip by the emperor Claudius in the same sinister context of revenge and punishment.

4 It is worth noting the anecdote's absence from both the Historia Augusta, Seu. 15, 7, and Herodian III 7, 4; III 9, 3-7, whereas both mention the other execution recorded here by Dio, that of Laetus. If one may trust the $H A$, Marius Maximus mentioned other executions, one of which may have been Crispus'.
} 
Dio's version is described by Millar ${ }^{5}$ as a rather flat paraphrase. Still, the Greek bears closer inspection. Lavinia's name is inserted to provide the context, possibly a recognition or assumption by Dio that some of his

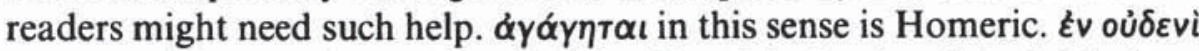
$\lambda o ́ \gamma \omega$ is undeniably flat and curt by the side of the Latin original; Dio here writes like the historian he is - to die unreported in a logos is the ultimate

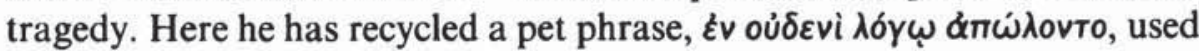
elsewhere (e.g. LIX 22, 4; LXXII 15, 1), tarting it up with a striking compound. $\pi \alpha \rho \alpha \pi \circ \lambda \lambda \dot{\mu} \mu \varepsilon \theta \alpha$ is an interesting choice of verb, thanks both to its connotation of purposeless waste and its use by Dio at LXIII 29, 2 in his version of what he calls the oft-quoted last words of Nero, i.e. qualis artifex pereo ${ }^{6}$.

2. To the account I gave some years ago of Virgil in Byzantium ${ }^{7}$ can be added a passage in the Chronicle of Malalas (12, p. 285 Bonn) where his explanation of the origin of the Maiuma festival - a controversial, indeed infamous, spectacle in his own time- is bolstered by adducing Aen . IV 302/3: trieterica Baccho / orgia nocturnusque uocat clamore Cithaeron. Malalas first quotes the passage in Latin, an interesting hint of the surviving interest in that language in sixth century Byzantium, especially at the relatively low cultural level of Malalas and his putative audience, then of-

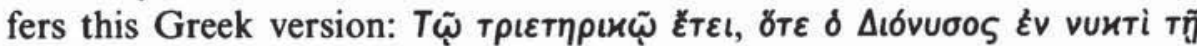

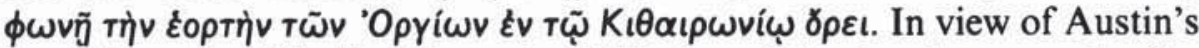
compliment to Virgil's alliterative skills here («Notice the many hard $c$ and $t$ sounds in the whole passage 300-3; the whole effect is one of noise»), one observes with interest the successful reproduction of these by Malalas $-11 t$ sounds and $3 k$.

B. BALDWIN

\footnotetext{
5 F. Millar, A Study of Cassius Dio, Oxford 1964, p. 143.

6 Not, despite what is popularly thought, the actual last words of the emperor in Suetonius, Nero 49, 1; even Syme, Tacitus, Oxford 1958, p. 41, is astray on this. It cannot be presumed that Dio is translating from the Latin of Suetonius (or the lost account of Tacitus), since a Greek source such as Plutarch's life of Nero could have provided the phrase. Or did the histrionic philhellene emperor, surrounded by Greek freedmen as he was, actually utter these words in Greek? He will in Suetonius subsequently produce 2 Greek tags, some mutterings in prose and a snatch from the Iliad, before expiring. One also notes that, according to Suetonius, Nero 54, Nero had pledged in the event of his retaining power to give a series of public demonstrations of his artistic talents, the culmination of which would be his dancing the role of Virgil's Turnus.

7 "Vergil in Byzantium», Ant. u. Abend. 28, 1982, pp. 81-8.
} 